\title{
Evaluation of antioxidant activity of grapevine leaves extracts (Vitis labrusca) in liver of Wistar rats
}

\author{
THAYS K. SCHAFFER ${ }^{1}$, MARIANE F. WOHLENBERG ${ }^{1}$, NIARA MEDEIROS ${ }^{1}$, JÉSSICA B. \\ MARTINS $^{1}$, FABIANA AGOSTINI ${ }^{2}$, CLÁUDIA FUNCHAL ${ }^{1}$ and CAROLINE DANI ${ }^{1}$ \\ ${ }^{1}$ Centro Universitário Metodista - IPA, Laboratório de Bioquímica, Centro de Pesquisas, \\ Rua Coronel Joaquim Pedro Salgado, 80, 90420-060 Porto Alegre, RS, Brasil \\ ${ }^{2}$ Universidade de Caxias do Sul, UCS, Laboratório de Óleos Essenciais, Rua Francisco \\ Getúlio Vargas, 1130, 95070-560 Caxias do Sul, RS, Brasil
}

Manuscript received on December 2, 2014; accepted for publication on March 3, 2015

\begin{abstract}
The aim of this study was to evaluate the hepatoprotection of organic and conventional grapevine leaves extract (Vitis labrusca). The total polyphenol content and the isolate polyphenols by HPLC were evaluate. The animals received intraperitoneal injections of saline or extracts (conventional or organic $-30 \mathrm{mg} / \mathrm{kg}$ ) for 14 days. On day 15, the rats received carbon tetrachloride $\left(\mathrm{CCl}_{4}\right)$ or mineral oil (i.p.). After $4 \mathrm{~h}$, the animals were euthanized. The analysis of the liver enzymes activity (AST, ALT, GGT) was performed using serum, obtained by blood and the levels of lipid peroxidation (TBARS), protein oxidation (carbonyl), and the activity of antioxidant enzymes superoxide dismutase and catalase were analyzed in the liver. The results showed that the organic extract is richer in polyphenol and resveratrol than the conventional one. Both extracts prevent lipid peroxidation and protein oxidation generated by $\mathrm{CCl}_{4}$. Moreover, the extracts demonstrated ability to modulate the activity of SOD and CAT, as well as to establish a balance in the ratio of SOD/CAT. We also found that the $\mathrm{CCl}_{4}$ increased the levels of AST and GGT, and that both extracts prevent this. These results indicate that grapevine leaves extracts, both, organic and conventional, can prevent liver disorders.
\end{abstract}

Key words: oxidative stress, carbon tetrachloride, hepatoprotection, grapes, phenolic compounds.

\section{INTRODUCTION}

Reactive species are highly unstable and extremely reactive in the human body (Sghaier et al. 2011). The imbalance between the production of reactive species and antioxidants is called oxidative stress; this condition is known as a cause of damage in biomolecules (DNA, lipids and proteins) and is

Correspondence to: Caroline Dani

E-mail: carolinedani@yahoo.com.br involved in the generation or aggravation of more than a hundred pathological conditions (Berger 2005). As a protection against oxidative damage, there are the antioxidants that are compounds capable of inhibiting or retarding oxidation of these molecules. Antioxidants may be enzymatic (endogenously produced) or non-enzymatic.Among the enzymatic, there are superoxide dismutase (SOD), catalase (CAT) and others (Halliwell and Gutteridge 2007). The non-enzymatic include 
polyphenols, widely distributed in plants, fruits, vegetables, leaves and in food (Faller and Fialho 2010). Among the fruits, grape is highlighted as one of the greatest sources of phenolic compounds, which are the main flavonoids (anthocyanins and flavanols), stilbenes (resveratrol) and phenolic acids (derivatives of cinnamic and benzoic acids) (Francis 2000).

Among the varieties of grape, Vitis labrusca is the oldest and best known of the American species. In Brazil, this variety has been used in the production of wines and grape juices, because they are more rustic and more productive, therefore, with lower growth costs than Vitis vinifera (Bourn and Prescott 2002, Dani et al. 2007). In the Brazilian markets, grapes and their derivatives can be from organic or conventional cultivar. The conventional ones are from vines that receive treatment with pesticides while the organic ones grow without the use of pesticides or other chemicals, and without genetic engineering (IFOAM 2005). It is known that organic farming provokes an increase in concentrations of total polyphenols (Soleas et al. 1997, Bourn and Prescott 2002). This result was already observed in grapevine leaves from Vitis labrusca (Dani et al. 2010), and in grape juices, where organic juice was shown to be richer in polyphenols than conventional juice (Dani et al. 2008a). Grapevines leaves are rich in phenolic compounds and have shown significant antioxidant activity in vitro and in vivo (Monagas et al. 2006, Kosar et al. 2007, Orhan et al. 2007, Pari and Suresh 2008, Dani et al. 2010, Oliboni et al. 2011).

Recent studies showed that the extracts from grapevines leaves of the Bordo variety (V. labrusca), both organic and conventional, prevent the damage caused by hydrogen peroxide in different tissues (liver, kidney, heart and brain tissues) from Wistar rats (Dani et al. 2010, Oliboni et al. 2011). In these studies, the extracts reduced the levels of lipid peroxidation and protein oxidation, in addition to modulating the activity of antioxidant enzymes.
Moreover, another study showed that the ethanolic extract of grapevine leaves of $V$. vinifera has hepatoprotective effects against damage caused by acetaminophen and carbon tetrachloride $\left(\mathrm{CCl}_{4}\right)$ (Orhan et al. 2007).

Among the models of the liver damage, $\mathrm{CCl}_{4}$ is a model of intoxication, widely used because it is able to induce oxidative stress and liver injury in experimental animals (Cemek et al. 2012), increasing lipid peroxidation and protein oxidation in the liver, resulting in damage generalized to the membrane (Ozturk et al. 2003). Thus, it is believed that liver injury $\mathrm{CCl}_{4}$-induced can be reduced by an antioxidant (Fujisawa et al. 2012). Given these considerations, until now, there are no published data demonstrating hepatoprotective effects of organic and conventional grapevine leaves extracts of $V$. labrusca in vivo. Thus, the aim of this study was to evaluate the levels of oxidative stress and antioxidant activity in liver of rats treated with grapevine leaves extracts of $V$. labrusca.

\section{MATERIALS AND METHODS}

\section{CHEMICAL REAGENTS}

Thiobarbituric acid was purchased from Merck (Darmstadt, Germany), and 2,4-Dinitrophenylhydrazine (DNPH, Brady's reagent) was obtained from Sigma (St. Louis, MO, USA). All other chemicals were of analytical grade and were purchased from local suppliers.

\section{GRAPEVINE LEAF EXTRACTS}

V. labrusca leaves, of the Bordo variety, from both conventional and organic grapevines, were collected in November 2011. The plants were identified by the Herbarium of the Centro Universitário Metodista - IPA. The organic grapevines received the ECOVIDA certification. The leaves were weighed and digested using Xpress digestion tubes (CEM Corporation, Matthews, NC, USA). Following digestion, Milli-Q (Millipore 
Corporation, Billerica, MA, USA) water was added to the tubes containing the leaves, and the mixture was subjected to microwave digestion. The samples were then transferred to a flask with Sarstedt focuser (Sarstedt Inc., Newton, NC, USA) with more Milli-Q water added. The samples were centrifuged and the supernatant obtained was used in all experiments. The final concentration was 0.1 $\mathrm{g} / \mathrm{mL}$.

\section{PHENOLIC COMPOUNDS}

The concentration of phenolic compounds was determined according to Singleton et al. 1999) modified, from the colorimetric method of FolinCiocalteau method (Singleton and Rossi 1999). The results were expressed as $\mathrm{mg} / 100 \mathrm{~g}$ of leaves.

Phenolic compounds were identified by HPLC and chlorogenic acid, taxifolin, ferulic acid, naringin, rutin, quercetin, luteolin, kaempferol, apigenin, catechin, epicatechin and resveratrol were analyzed. All patterns were evaluated by HPLC HP 1100, Lispher RP18 (5 mM) column equipped with a UV detector and a quaternary pump system, with a flow rate of $1.0 \mathrm{~mL} / \mathrm{min}$ and an injection volume of $50 \mu \mathrm{L}$, and results were expressed in $\mu \mathrm{g} / \mathrm{mL}$. The quantification of catechin was performed as described by Saucier et al. (2001). Solvent A contained water with 5\% acetic acid; solvent B contained methanol with $5 \%$ acetic acid; isocratic elution $90 \% \mathrm{~A}$ and $10 \%$ solvent $\mathrm{B}$, total analysis time, $45 \mathrm{~min}$, detection at $280 \mathrm{~nm}$ (Saucier et al. 2001). For quantification of rutin, quercetin, kaempferol and naringin, solvent A contained methanol with $2 \%$ acetic acid and solvent B Milli-Q water with $2 \%$ acetic acid, total analysis time, $60 \mathrm{~min}$, detection at $350 \mathrm{~nm}$. The method of alkaloids system was gradient elution reversed-phase column: RP18, detection: $280 \mathrm{~nm}$, flow: $1 \mathrm{~mL} /$ minute, analysis time: $45 \mathrm{~min}$ and column temperature: $25^{\circ} \mathrm{C}$ (Fillip et al. 2001). For quantification of resveratrol, solvent A contained water with $\mathrm{pH} 2.5$; solvent $\mathrm{B}$, methanol; gradient of
$90 \%$ solvent A and $10 \%$ solvent B to $100 \%$ solvent $\mathrm{B}$; total analysis time of $45 \mathrm{~min}$, with detection at $313 \mathrm{~nm}$ (Ector et al. 1996). All standards were purchased from Fluka Analytical (St. Gallen, Switzerland), Sigma-Aldrich

ANIMALS

Thirty male Wistar rats, from the bioterium of the Centro Universitário Metodista - IPA, aged 90 days, weighing approximately 300 grams were used in this experiment. The animals had free access to water and commercial diet containing $20.5 \%$ protein (predominantly soybean), 54\% carbohydrate, $4 \%$ fat, $4.5 \%$ fiber, $7 \%$ ash and $10 \%$ moisture. The animals were maintained on a $12 \mathrm{~h}$ light/ $12 \mathrm{~h}$ dark cycle at a temperature of $22{ }^{\circ} \mathrm{C} \pm 1$ ${ }^{\circ} \mathrm{C}$. All experimental procedures were performed with the approval of the Ethics Commission for Animal Use of the Centro Universitário Metodista - IPA n ${ }^{\circ} 03 / 2012$.

\section{TREATMENT}

Once a day, all animals received a single intraperitoneal injection for 14 days. Based on a previous study (Dani et al. 2008a), the animals were divided into three experimental groups $(\mathrm{n}=10 / \mathrm{each})$. Group 1 (Control) received saline (0.9\%); Group 2 received conventional grapevine leaf extract (30 $\mathrm{mg} / \mathrm{kg}$ ); and group 3 received organic extract (30 $\mathrm{mg} / \mathrm{kg}$ ). On the $15^{\text {th }}$ day, half of the animals in each group received a single intraperitoneal dose of $\mathrm{CCl}_{4}$ $(3 \mathrm{~mL} / \mathrm{kg}$ ) and the other half, a single dose, also intraperitoneally, of the mineral oil (control). After $4 \mathrm{~h}$, the animals were euthanized by decapitation. The liver was dissected and homogenized in $1.5 \%$ $\mathrm{KCl}$ solution in manual homogenizer, and stored in a freezer $\left(-80^{\circ} \mathrm{C}\right)$ until the analysis.

PARAMETERS OF OXIDATIVE STRESS

As an index of lipid peroxidation, we used thiobarbituric acid reactive species (TBARS) 
production during an acid-heating reaction, which is widely adopted as a sensitive method for measuring lipid peroxidation, as previously described by Wills (1996). The samples were mixed with $10 \%$ trichloroacetic acid (TCA) and $0.67 \%$ thiobarbituric acid (TBA) and then heated in a boiling water bath for $15 \mathrm{~min}$ in closed tubes. TBARS were determined by absorbance at 535 nm (Wills 1996). Results were expressed as nmol/ $\mathrm{mg}$ of protein. Oxidative damage to proteins was assessed by determining carbonyl groups based on the reaction with dinitrophenylhydrazine (DNPH), as previously described by Levine et al. (1990). DNPH reacted with protein carbonyls to form hydrazones that could be measured with a spectrophotometer. $500 \mu \mathrm{L}$ of $10 \mathrm{mM} \mathrm{DNPH}$ in $2 \mathrm{M} \mathrm{HCl}$ at room temperature were added for $1 \mathrm{~h}$, with vortexing every $10-15 \mathrm{~min}$. Then $500 \mu \mathrm{L}$ of $20 \%$ trichloroacetic acid were added, centrifuged for $3 \mathrm{~min}$, and discarded the supernatant. The pellets were washed three times with $1 \mathrm{~mL}$ ethanolethyl acetate (1:1) to remove free reagent. After centrifugation, the protein precipitation was again dissolved in $0.6 \mathrm{~mL}$ guanidine solution. Proteins were dissolved within $15 \mathrm{~min}$ at $37^{\circ} \mathrm{C}$. The insoluble materials were removed by centrifugation in the microcentrifuge for $3 \mathrm{~min}$. The absorbance was read at $370 \mathrm{~nm}$. Equal amounts of protein samples without DNPH were used as controls (Levine et al. 1990). Results were expressed in $\mathrm{nmol} / \mathrm{mg}$ of protein.

\section{DETERMINATION OF ANTIOXIDANTS ENZYMES}

The activity of SOD was determined by spectrophotometric method, measuring the inhibition of the formation rate adenocromo at 480 nm (SP-2200 Spectrophotometer, Bioespectro) in medium containing $1 \mathrm{mM}$ adrenalin and $50 \mathrm{mM}$ glycine (Bannister and Calabrese 1987). Results were expressed in USOD/mg of protein. The method used to determine the CAT activity has been described by Aebi (1984) and determines the rate of degradation of $\mathrm{H}_{2} \mathrm{O}_{2} 240 \mathrm{~nm}$ (Spectrophotometer SP-2200, Bioespectro). The results were expressed as UCAT/mg protein (Aebi 1984).

\section{PROTEIN DETERMINATION}

Protein concentrations were determined according to the method described by Lowry et al. (1951) (Lowry et al. 1951).

\section{OBTAINING THE SERUM}

The blood was drawn in tubes without anticoagulant, centrifuged at $800 \mathrm{Xg}$ for $10 \mathrm{~min}$ and the serum was kept refrigerated $\left(-4^{\circ} \mathrm{C}\right)$ until analysis.

\section{ANALYSIS OF LIVER ENZYMES}

Liver function was evaluated by measuring alanine aminotransferase (ALT), aspartate aminotransferase (AST), and gamma-glutamiltranspepeptidase (GGT). The assays were performed using commercial kits (Labtest, Diagnostica SA, Minas Gerais, Brazil).

\section{STATISTICAL ANALYSES}

Results were expressed as mean and standard deviation. The data were tested for normality using the Kolmogorov-Smirnov test. We observed the normal distribution of data. The differences between all the groups were analyzed by means of a three-way variance (ANOVA), followed by Tukey's post-test. For comparison between two means, the Student's t-test was used, $\mathrm{p}<0.05$ was considered significant. All analyses were performed using the statistical program Statistical Package for the Social Sciences (SPSS) version 17.0.

\section{RESULTS}

Products derived from vine are known for being rich in phenolic compounds. Our results showed that both, organic and conventional extracts were rich in phenolic compounds, however they presented statistically significant differences in the content 
of total polyphenols, resveratrol and catechin ( $\mathrm{p}$ $<0.05)$. In relation to total polyphenols, the organic extract had higher values $(81.78 \pm 2.67)$ than the conventional extract $(19.83 \pm 0.75)$. For the content of resveratrol, the organic extract also has showed higher values $(0.04 \pm 0.004)$ than the conventional extract $(0.01 \pm 0.003)$. Concerning the content of catechin, the conventional extract presented higher values $(211.82 \pm 5.05)$ than the than the organic extract $(161.09 \pm 0.96)$. Phenolic compounds as rutin, quercetin, naringin, kaempferol, chlorogenic acid, taxifolin, ferulic acid, luteolin and apigenin were not detected in the analysis.

In this study, the hepatoprotective effects were evaluated by the ability to prevent lipid peroxidation and protein oxidation, to alter in the superoxide dismutase (SOD) and catalase (CAT) enzyme, as well as the their relationship, and also to analyze of liver enzymes (AST, ALT and GGT). Our results demonstrated that the $\mathrm{CCl}_{4}$ induced lipid peroxidation and protein oxidation and that
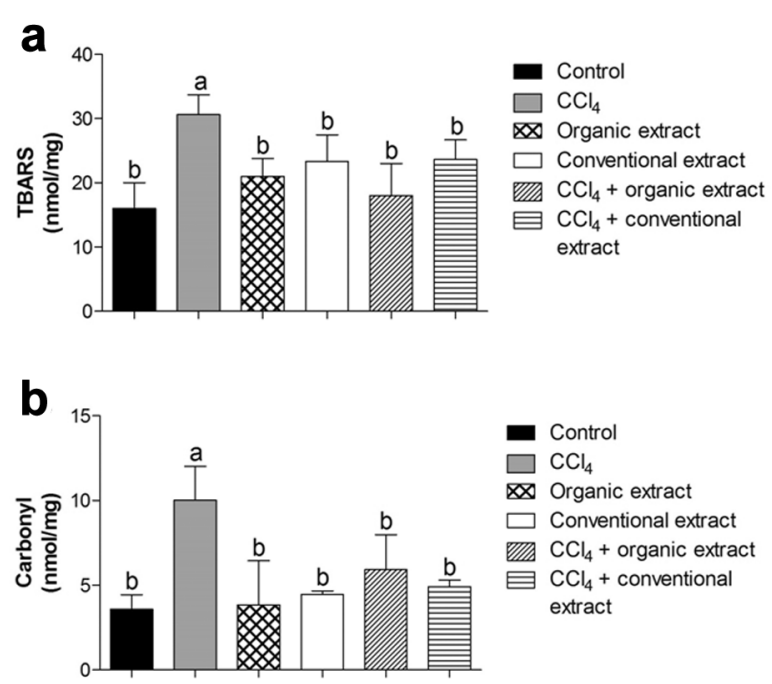

Figure 1 - (a) Levels of thiobarbituric acid reactive species (TBARS) (nmol/mg) and (b) Carbonyl (nmol/mg protein) in liver tissues of rats treated with different extracts (organic and conventional) and carbon tetrachloride $(3 \mathrm{~mL} / \mathrm{kg})$. Data are expressed as mean $\pm \mathrm{SD}$. Different letters indicate statistical difference according to ANOVA and Tukey's post-test ( $\mathrm{p}<$ 0.05 ) for each tissue evaluated. both extracts, conventional and organic, prevented this damage, equaling the value of the control group. The extracts by themselves did not alter the values (Fig. 1). When analyzing the activity of SOD enzyme, it was observed that $\mathrm{CCl}_{4}$ reduced the activity of this enzyme, and this reduction was potentiated with the extracts plus $\mathrm{CCl}_{4}$. The extracts alone decreased the SOD activity (Fig. 2a). In the CAT enzyme activity, the $\mathrm{CCl}_{4}$ also reduced the activity of this enzyme, and the extracts prevented this reduction (Fig. 2b). In the ratio $\mathrm{SOD} / \mathrm{CAT}$, $\mathrm{CCl}_{4}$ increased this parameter and both extracts reduced this parameter, and the extracts alone did not change (Fig. 2c).
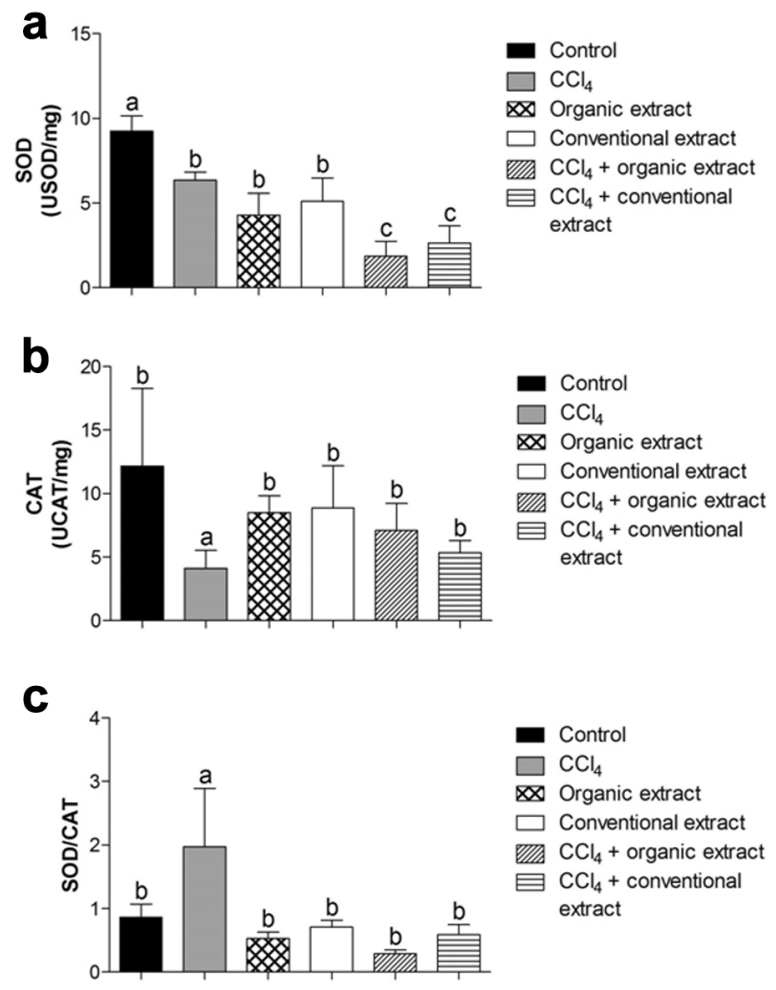

Figure 2 - (a) Superoxide dismutase (SOD) activity (USOD/ $\mathrm{mg}$ protein) (b) Catalase (CAT) activity (UCAT/mg protein) and (c) SOD/CAT ratio in liver tissues of rats treated with different extracts (organic and conventional) and carbon tetrachloride $(3 \mathrm{~mL} / \mathrm{kg})$. Data are expressed as mean $\pm \mathrm{SD}$. Different letters indicate statistical difference according to ANOVA and Tukey's post-test $(p<0.05)$ for each tissue evaluated. 
In hepatic profile (Fig. 3a), we found that ALT levels were not affected by any of the treatments. However, we observed that the $\mathrm{CCl}_{4}$ increased AST (Fig. 3b) and GGT (Fig. 3c) levels and both extracts were able to prevent this increase.
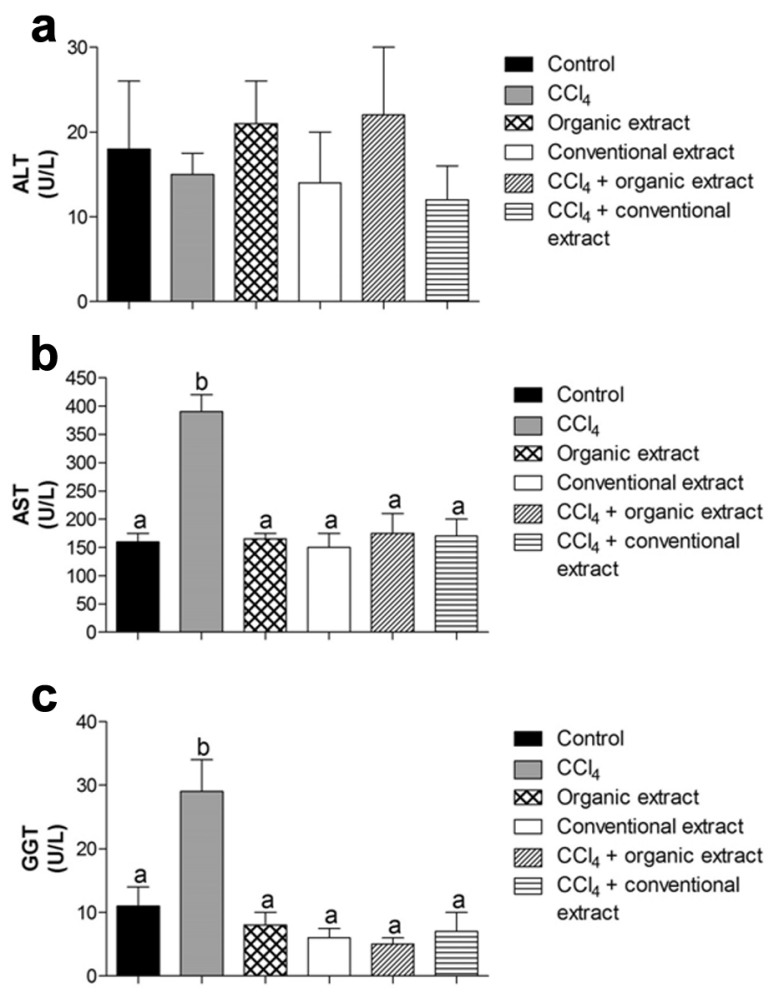

Figure 3 - (a) Aspartate aminotransferase (AST) (U/L) (b) Alanine aminotransferase (ALT) (U/L) (c) Gamma-Glutamyl Transferase (GGT) (U/L) in serum of rats treated with different extracts (organic and conventional) and carbon tetrachloride $(3 \mathrm{~mL} / \mathrm{kg})$. Data are expressed as mean \pm SD. Different letters indicate statistical difference according to ANOVA and Tukey's post-test $(\mathrm{p}<0.05)$ for each tissue evaluated.

\section{DISCUSSION}

The grapevine leaves are composed of a variety of polyphenols which include anthocyanins, flavanoids, tannins, and procyanidins (Pari and Suresh 2008). In our study we observed that the organic extract of grapevine leaves $V$. labrusca presented higher levels of total polyphenols and resveratrol, which was also observed for organic grape juices (Dani et al. 2007, 2008a) and grapevine leaves extracts (Dani et al. 2010). With regards to the content of catechin, the conventional extract showed higher values than the organic extract, which corroborates findings in grapevine leaves extracts, both organic and conventional, of $V$. labrusca (Dani et al. 2010, Oliboni et al. 2011). Many factors can affect the amount of phenolic compounds, among them, genetic factors, climate, soil conditions, degree of ripeness, postharvest storage and growth method (organic or conventional) (Mikašauskaite et al. 2013). Another explanation for the levels of these compounds being higher in the organic extract is that, as pesticides are not used, the plants are more susceptible to the action of pathogenic organisms, and as a form of defense they produce large amounts of phenolic compounds (Soleas et al. 1997, Bourn and Prescott 2002).

Polyphenols are antioxidants that are frequently and on a large scale, present in our diet (Nunez et al. 2004). This is attributed to these compounds ability to inhibit lipid peroxidation, platelet aggregation and capillary permeability (Mateos et al. 2005). In our study, $\mathrm{CCl}_{4}$ induced lipid peroxidation (TBARS) and protein oxidation (Carbonyl) in the liver. The extracts prevented this damage, both similarly, corresponding to the control value, promoting hepatoprotection. These results corroborate with Orhan et al. (2007), they showed that ethanol extracts of grapevine leaves $V$. vinifera were able to reduce the damage caused by $\mathrm{CCl}_{4}$ in the liver of rats (Orhan et al. 2007). The same occurred in extracts of $V$. labrusca against damage caused by hydrogen peroxide $\left(\mathrm{H}_{2} \mathrm{O}_{2}\right)$ in liver tissue of rats in an in vitro study (Oliboni et al. 2011). This benefit of derivatives of grape was also demonstrated in a study with grape juice ( $V$. labrusca), showing their ability to reduce the level of lipid peroxidation in liver and plasma, induced by $\mathrm{CCl}_{4}$ (Dani et al. 2008a). The hepatoprotection can be attributed to the polyphenol; Oliboni et al. (2011) demonstrated significant correlations 
between the polyphenol content and the reduction of lipid peroxidation and protein oxidation (Oliboni et al. 2011).

In analyzing the activity of SOD enzyme, it was observed that $\mathrm{CCl}_{4}$ reduced the activity of this enzyme, and the association with extracts further increased this reduction. $\mathrm{CCl}_{4}$-induced reduction may be attributed to the generation of the reactive specie $\mathrm{H}_{2} \mathrm{O}_{2}$, which is the product of the enzymatic reaction performed by SOD. According to Mittal and Kant (2009), with increased oxidative stress, SOD decreases due to irreversible inactivation by its product, $\mathrm{H}_{2} \mathrm{O}_{2}$ (Mittal and Kant 2009). This reduction also increases when combined with the extracts, which may be attributed to the effect of the polyphenols that could be playing the role of the "SOD-like" enzyme acting as antioxidants (Calderón et al. 2009). This corroborates a study using grapevine leaves extracts of $V$. labrusca against the damage generated by $\mathrm{H}_{2} \mathrm{O}_{2}$ in liver tissues, where a reduction in enzyme activity in the presence of conventional extract associated with an inductor damage agent was observed (Oliboni et al. 2011).

In CAT enzyme activity, the $\mathrm{CCl}_{4}$ also reduced CAT activity, but the extracts reversed this reduction. The same was observed in a recent study with grapevine leaves extracts of V. labrusca, both organic and conventional, against damage generated by $\mathrm{H}_{2} \mathrm{O}_{2}$, where conventional extract restored CAT activity in the liver of rats, which had been earlier reduced by an inductor damage agent (Oliboni et al. 2011). Similar also, was observed in a study of grape juice $V$. labrusca against $\mathrm{CCl}_{4}$ induced damage in the brain of rats, and the juice restored the activity of this enzyme (Dani et al. 2008b).

Our study also demonstrated that the SOD/ CAT ratio was increased in the $\mathrm{CCl}_{4}$ group. The addition of extracts showed a reduction in this ratio. This parameter is extremely important because with the imbalance between these two enzymes, oxidative damage can be induced, and this occurs in some diseases (Dal-Pizzol et al. 2001, 2003). The SOD activity leads to the production of $\mathrm{H}_{2} \mathrm{O}_{2}$, which can react with iron through Fenton reaction to generate hydroxyl radicals, which are considered the most toxic oxygen molecules in vivo (Halliwell and Gutteridge 2007). In this sequence CAT sequesters excessive $\mathrm{H}_{2} \mathrm{O}_{2}$, avoiding its potential role as a facilitator molecule to oxidative stress. Our results suggest that in the groups receiving grapevine leaves extracts, the balance between the enzymes demonstrated a better state of antioxidant protection. This balance was also observed in a study where rats were treated with grape juice V. labrusca against damage generated by $\mathrm{CCl}_{4}$ in liver tissue (Dani et al. 2007). In the same study this parameter was increased in the $\mathrm{CCl}_{4}$ group and after the treatment with grape juice, the values were reduced (Dani et al. 2007). These authors reported that this imbalance involves an increase in $\mathrm{H}_{2} \mathrm{O}_{2}$ production that in turn reacts with iron through Fenton reaction and thereby produces hydroxyl radicals.

Regarding liver enzymes, this study showed no significant change in ALT, but there was an increase in AST. This can be explained by the fact that AST is present in the cytosol and mitochondria of hepatocytes. Plasma activity of this enzyme is controlled by a release mechanism located on the hepatocyte membrane (Miller and Gonçalves 1999); $\mathrm{CCl}_{4}$ is a hepatotoxic drug capable of causing cell damage, and the death of the hepatocyte (Cremonese et al. 2001). Thus, we observed that $\mathrm{CCl}_{4}$ induced liver injury. It was also shown that the activity of AST and GGT was increased in the groups that received only $\mathrm{CCl}_{4}$ and that both extracts, conventional and organic, were able to prevent this increase.

Hepatoprotective action by polyphenols compounds was showed by Khan et al. (2012). In this study, rutin, an important polyphenol, showed a hepatoprotective effect against the damage induced 
by $\mathrm{CCl}_{4}$ in rats, decreasing the levels of AST and GGT, indicating the effect of this compound (Khan et al. 2012). These benefits effects from polyphenols against damage caused by $\mathrm{CCl}_{4}$ were also demonstrated by Zhen et al. (2007). In this study, the epigallocatechin-3-gallate (EGCG),a polyphenol appointed as main active ingredient of green tea (Suganuma et al. 1999, Zhen et al. 2007), demonstrated a significant decrease on levels of ALT and AST in rats. Sreelatha et al. (2009) in their study with $\mathrm{CCl}_{4}$ and with extracts of Coriandrum sativum also observed a reduction in the levels of AST and ALT after treatment with $\mathrm{CCl}_{4}$ (Sreelatha et al. 2009). The decrease in serum levels of these enzymes can be a result of the stabilization of the plasma membrane as well as the repair of liver tissue damage, caused by $\mathrm{CCl}_{4}$ (Thabrew et al. 1987). In another study conducted with grapevine leaf extract of Vitis vinifera, it was shown that this extract was able to reduce the activity of these enzymes when they were increased due to the administration of alcohol (Pari and Suresh 2008).

Through these results, we can attribute to the grapevine leaves extracts of V. labrusca, both organic and conventional, an important participation in the prevention of diseases associated with oxidative stress, in particular relating to the liver. Furthermore, it is important to highlight that, synthetic drugs used in the treatment of liver diseases are often insufficient and may cause severe adverse effects (Cemek et al. 2012). The use of natural compounds and food supplements as an alternative to prevent and/or treat liver diseases seems to be a great option and can be confirmed through further studies.

\section{RESUMO}

O objetivo deste estudo foi avaliar a hepatoproteção do extrato de folhas de videira (Vitis labrusca) orgânica e convencional. Foram avaliados o conteúdo de polifenóis totais e os polifenóis isolados por HPLC. Os animais receberam injeções intraperitoneais de salina ou extratos (de folha orgânica ou convencional - $30 \mathrm{mg} / \mathrm{kg}$ ), durante
14 dias. No $15^{\circ}$ dia, os ratos receberam tetracloreto de carbono $\left(\mathrm{CCl}_{4}\right)$ ou óleo mineral (i.p.). Após 4 horas, os animais foram eutanasiados. A análise da atividade das enzimas hepáticas (AST, ALT, GGT) foi feita usando soro, obtido através do sangue e os níveis de peroxidação lipídica (TBARS), oxidação proteica (Carbonil), e da atividade das enzimas antioxidantes superóxido dismutase e catalase foram analisados no fígado. Os resultados demonstraram que o extrato orgânico é mais rico em polifenol e resveratrol do que o convencional. Ambos os extratos previnem a peroxidação lipídica e oxidação proteica gerada pelo $\mathrm{CCl}_{4}$. Além disto, os extratos demonstraram capacidade em modular a atividade de SOD e CAT, bem como em estabelecer um equilíbrio na relação de SOD/CAT. Nós também encontramos que o $\mathrm{CCl}_{4}$ aumentou os níveis de AST e GGT, e que ambos os extratos previnem isto. Estes resultados indicam que os extratos de folhas de videira, ambos, orgânico e convencional, podem prevenir desordens do fígado.

Palavras-chave: estresse oxidativo, tetracloreto de carbono, hepatoproteção, uvas, compostos fenólicos.

\section{REFERENCES}

AEBI H. 1984. Catalase in vitro. Methods Enzymol 105: 121126.

BANNISTER JV AND CALABRESE L. 1987. Assays for SOD. Methods Biochem Anal 353: 279-312.

BERGER MM. 2005. Can oxidative damage be treated nutritionally? Clin Nutr 24: 172-183.

BOURN D AND PRESCOTT J. 2002. A comparison of the nutritional value, sensory qualities and food safety of organically and conventionally produced foods. Crit Rev Food Sci Nutr 42: 1-34.

CALDERÓN AI, Wright NJ, HURST WJ AND BREEMEN RB. 2009. Screening antioxidants using LC-ms: case study with Cocoa. J Agric Food Chem 57: 5693-5699.

CEMEK M, YILMAZ F, BUYUKOKUROGLU ME, BUYUKBEN A, AYMELEK F AND AYAZ A. 2012. Serum and Liver Tissue Bio-Element Levels, and Antioxidant Enzyme Activities in Carbon Tetrachloride-Induced Hepatotoxicity: Protective Effects of Royal Jelly. J Med Food 15: 747-752.

Cremonese RV, PEREIRA-Filho AA, MAGAlhães R, MAtTos AA, MARroni CA, ZETTLER CG AND MARRONI NP. 2001. Experimental cirrhosis induced by carbon tetrachloride inhalation: adaptation of the technique and evaluation of lipid peroxidation. Archives of Gastroenterology 38: 40-47.

DAL-PIZZOL F, KLAMT F, BENFATO MS, BERNARD EA AND MOREIRA JC. 2001. Retinol supplementation induces 
oxidative stress and modulates antioxidant enzyme activities in rat Sertoli cells. Free Radic Res 34: 395-404.

Dal-Pizzol F, RitTer C, Klamt F, Andrades M, DA Frota ML JR, Diel C, DE Lima C, BRAGA FILHO A, SCHWARTSMANN G AND MOREIRA JC. 2003. Modulation of oxidative stress in response to gamma-radiation in human glioma cell lines. J Neurooncol 61: 8994.

DANI C, OLIBONI LS, PASQUALI MA, OLIVEIRA MR, UMEZU FM, SAlVAdor M, Moreira JC AND HENRIQUes JA. 2008a. Intake of Purple Grape Juice as a Hepatoprotective Agent in Wistar Rats. J Med Food 127-132.

DANi C, OLIBOni LS, VANDERLinde R, BonatTo D, SALVADOR M AND HENRIQUES JA. 2010. Phenolic content of grapevine leaves (Vitis labrusca var. Bordo) and its neuroprotective effect against peroxide damage. Toxicol In Vitro 24: 148-153.

DANi C, OLIBONi LS, VANDERLinde R, BONATTO D, SALVADOR M AND HENRIQUES JAP. 2007. Phenolic content and antioxidant activities of white and purple juices manufactured with organically- or conventionallyproduced grapes. Food Chem Toxicol 45: 2574-2580.

DANi C, PASQUALi MA, OliVeira MR, UMEZU FM, SALVADOR M, HENRIQUES JA AND MOREIRA JC. 2008b. Protective effects of purple grape juice on carbon tetrachloride induced oxidative stress in brains of adult Wistar rats. J Med Food 11: 55-56.

ECTOR BJ, MAGEe JB, HeGWOOd CP AND COIGN MJ. 1996. Resveratrol concentration in muscadine berries, juice, pomace, purees, seeds, and wines. Am J Enol Vitic 47: 57-62.

FALLER AL AND FIALHO E. 2010. Polyphenol content and antioxidant capacity in organic and conventional plant foods. J Food Compos Anal 23: 561-568.

FILLIP R, LÓPEZ P, GILBERTI J, COUSSIO J AND FERRARO G. 2001. Phenolic compounds in seven South American Ilex species. Fitoterapia 72: 774-778.

FRANCIS FJ. 2000. Anthocyanins and betalains: composition and applications. Cereal Foods World 45: 208-213.

FUJISAWA K, YABUUCHI C, IZAWA T, KUWAMURA M, TAKASU N, TORII M AND YAMATE J. 2012. Expression patterns of heat shock protein 25 in carbon tetrachlorideinduced rat liver injury. Exp Toxicol Pathol 65: 469-476.

HALLIWELl B AND GUTTERIDGE JM. 2007. Free Radicals in Biology and Medicine, $4^{\text {th }}$ ed., Oxford: Clarendon Press.

IFOAM - INTERNATIONAL FEDERATION OF ORGANIC MOVIMENTS. 2005. Disponível em: <http://www.ifoam. org> Acesso: 18 de setembro de 2011.

KHAN RA, KHAN MR AND SAHREEN S. 2012. $\mathrm{CCl}_{4}$-induced hepatotoxicity: protective effect of rutin on p53, CYP2E1 and the antioxidative status in rat. BMC Complement Altern Med 12: 178.

KosAR, M, KÜPELI E, MALYER H, UYLASER V, TÜRKBEN C AND BASER KH. 2007. Effect of brining on biological activity of leaves of Vitis vinifera L. (Cv. Sultani Cekirdeksiz) from Turkey. J Agric Food Chem 55: 45964603.

LEVINE RL, GARLAND D, OLIVER CN, AMici A, Climent I, LENZ AG, AHN BW, SHALTIEL S AND STADTMAN ER. 1990. Determination of carbonyl content in oxidatively modified proteins. Methods Enzymol 186: 464-78.

LOWRY OH, ROSEBROUGH NJ, FARR AL AND RANDALL RJ. 1951. Protein measurement with the folin phenol reagent. J Biol Chem 193: 265-267.

MATEOS R, LECUMBERRI E, RAMOS S, GOYA L AND BRAVO L. 2005. Determination of malondialdehyde (MDA) by high-performance liquid chromatography in serum and liver as a biomarker for oxidative stress. Application to a rat model for hypercholesterolemia and evaluation of the effect of diets rich in phenolic antioxidants from fruits. J Chromatogr B Analyt Technol Biomed Life Sci 827: 7682.

Miller O AND GONÇALVES RR. 1999. Laboratório para o clínico. $8^{\text {th }}$ ed., São Paulo: Atheneu, 607 p.

MIKAŠAUSKAITĖ J, RAGAŽINSKIENĖ O AND MARUŠKA A. 2013. Variation of total amount of phenolic compounds, radical scavenging activity and volatile com pounds of Liriodendron tulipifera L. and Ginkgo biloba L. leaves extracts during different vegetation periods. Biologija 59: 175-186.

MITTAL PC AND KANT R. 2009. Correlation of increased oxidative stress to body weight in disease-free post menopausal women. Clin Biochem 42: 1007-1011.

MONAGAS M, HERnÁNDEZ-LEdesma B, GómeZCORDOVÉS C AND BARTOLOMÉ B. 2006. Commercial dietary ingredients from Vitis vinifera L. leaves and grape skins: antioxidant and chemical characterization. J Agric Food Chem 54: 319-327.

Nunez V, MONAGAS M, GOMEZ-CORDOVÉS MC AND BARTOLOMÉ B. 2004. Vitis vinifera L. cv. Graciano grapes characterized by its anthocyanin profile, Postharvest Biol Technol 31: 69-79.

OLIBONI LS, DANi C, FUnCHAL C, HenRiques JA AND SALVADOR M. 2011. Hepatoprotective, cardioprotective, and renal-protective effects of organic and conventional grapevine leaf extracts (Vitis labrusca var. Bordo) on Wistar rat tissues. An Acad Bras Cienc 83: 1403-1411.

ORHAN DD, ORHAN N, ERGUN E AND ERGUN F. 2007. Hepatoprotective effect of Vitis vinifera L. leaves on carbon tetrachloride-induced acute liver damage in rats. J Ethnopharmacology 112:145-151.

OZTURK F, UCAR M, OZTURK IC, VARDI N AND BATCIOGLU K. 2003. Carbon tetrachloride-induced nephrotoxicity and protective effect of betaine in Sprague-Dawley rats. Urology 62: 353-356.

PARI L AND SURESH A. 2008. Effect of grape (Vitis vinifera L.) leaf extract on alcohol induced oxidative stress in rats. Food Chem Toxicol 96: 1627-1634. 
SAUCIER C, Mirabel M, DAVIUd F, LONGIERAS A AND GLORIES T. 2001. Rapid fractionation of grape seeds proanthocyanidins. J Agr Food Chem 49: 5732-5735.

SGHAIER MB, BHOURI W, NEFFATI A, BOUBAKER J, SKANDRANI I, BOUHLE I, KILANI S, CHEKIR-GHEDIRA L AND GHEDIRA K. 2011. Chemical investigation of different crude extracts from Teucrium ramosissimum leaves. Correlation with their antigenotoxic and antioxidant properties. Food Chem Toxicol 49: 191-201.

SINGLETON VL, ORTHOFER R AND LAMUELA-RAVENTOS RM. 1999. Analysis of total phenols and other oxidation substrates and antioxidants by means of Folin-Ciocalteau reagent. Methods in Enzymology, Oxidant and Antioxidant 159-178.

Soleas GJ, DiAmANDis EP AND GOLDBERG DM. 1997. Resveratrol: a molecule whose time has come? And gone? Clin Biochem 30: 91-113.

SReElatha S, PADMA PR AND UMAdEVI M. 2009. Protective effects of Coriandrum sativum extracts on carbon tetrachloride-induced hepatotoxicity in rats. Food and Chemical Toxicology 47: 702-708.

SugANuma M, OKABE S, KAI Y, SUEOKA N, SUEOKA E AND FUJIKI H. 1999. Synergistic effects of (-)-epigallocatechin gallate with (-)-epicatechin, sulindac, or tamoxifen on cancer-preventive activity in the human lung cancer cell line PC-9. Cancer Res 59: 44-47.

THABREW MI, JoICE PD AND RAJATISSA WA. 1987. Comparative study of efficacy of Paetta indica and Osbeckia octandra in the treatment of liver dysfunction. Planta Medica 53: 239-241.

WILLS ED. 1996. Mechanism of lipid peroxide formation in animal tissues. Biochem J 99: 667-676.

ZHEN MC, WANG Q, HUANG XH, CAO LQ, CHEN XL, SUN K, LIU YJ, LI W AND ZHANG LJ. 2007. Green tea polyphenol epigallocatechin-3-gallate inhibits oxidative damage and preventive effects on carbon tetrachlorideinduced hepatic fibrosis. J Nutr Biochem 18: 795-805. 